\title{
Economic growth and environmental degradation at Indian context : Environmental Kuznets Curve (EKC) approach
}

\section{K. VIJAYALAXMI AND V. SARAVANAKUMAR}

Article Chronicle :

Received :

30.03.2017;

Revised :

13.05.2017;

Accepted :

25.05.2017

\section{Key Words :}

EKC,

Environmental, Degradation, Cointegration
ABSTRACT : Environmental pollution is an important issue in the process of economic growth. The deterioration of environment begins to have direct impact on the quality of human life or even a threat to the survival of human being. This paper investigates the relationship between per capita gross domestic product (GDP) and per capita $\mathrm{CO}_{2}$ emissions as hypothesized by Environmental Kuznets Curve (EKC) holds in the long-run or not. Co-integration regression methodology is employed for examining the long run relationship between the variables. For this purpose time series data on GDP and $\mathrm{CO}_{2}$ emission along with foreign direct investment (FDI) and population density (PD) are been taken from year 1991 to 2015 . The results revealed that there is no inverted ' $U$ ' shaped relationship between per capita GDP and per capita $\mathrm{CO}_{2}$ emissions i.e., EKC hypothesis has failed at Indian condition to explain the inverted relationship between GDP and $\mathrm{CO}_{2}$ emission. It indicates that increase in per capita GDP strongly leads to economic growth and welfare of the people while it doesn't cause $\mathrm{CO}_{2}$ emissions in India.

HOW TO CITE THIS ARTICLE : Vijayalaxmi, D.K. and Saravanakumar, V. (2017). Economic growth and environmental degradation at Indian context : Environmental Kuznets Curve (EKC) approach. Asian J. Environ. Sci., 12(1): 57-59, DOI: 10.15740/HAS/AJES/12.1/57-59.
Author for correspondence : D.K. VIJAYALAXMI Department of Agricultural Economics, Tamil Nadu Agricultural University, COIMBATORE (T. N.) INDIA

Email : vijayalaxmikhed39@ gmail.com

See end of the article for Coopted authors' 